\title{
THE EMBRACE OF THE DARK CLOUD
}

\section{GONZALO VALIENTE ORIOL}

Académico, Faculty of Design, Architecture and Building, University of Technology Sydney, Sydney, Australia

\section{JORGE VALIENTE ORIOL}

Académico, Faculty of Design, Architecture and Building, University of Technology Sydney, Sydney, Australia

\section{AMAIA SÁNCHEZ VELASCO}

Académica, Faculty of Design, Architecture and Building, University of Technology Sydney, Sydney, Australia

\section{MIGUEL RODRÍGUEZ-CASELLAS}

Académico, Faculty of Design, Architecture and Building, University of Technology Sydney, Sydney, Australia

Starting from a cloud of smoke that connected two distant cities at the beginning of 2020, this essay explores the historical similarities between these two Pacific ports - Sydney and Valparaíso. Analyzing the commonalities and divergences between Australian and Chilean neoliberalism, the collapse of this model is evidenced in the smoke from fires or barricades that could give rise to new forms of post-liberal coexistence.

\section{Act 1: Prelude}

On January 7, 2020, a black cloud appears uninvited at six thousand meters above the Chilean central area. This atmospheric formation is not an explicable phenomenon from common meteorology. It is a column of smoke emitted by the tragic fires that ravaged the Australian eastern coast during the summer of 2019-20, which connected, without intermission, the more than 11,000 $\mathrm{km}$ that span between both ends of the Pacific Ocean ${ }^{1}$. With the gloomy passage of a Greek chorus, the stretched formation clung to the push of the oceanic winds to establish a dramatic dialogue between two cities besieged by armies of murderous smoke and whose disastrous connection allows us to playfully unravel the imageries of courage, desire, and pertinence, that neoliberal common sense insists on framing within a context of the inevitable.

Connected by the pilgrimage of forest smoke, Sydney (Australia) and Valparaíso (Chile) are two cities of port memory and colonial grounds embraced by the Pacific Ocean. Being both central figures of vast metropolitan regions, their bones, entrails, and skins crystallize asymmetric legacies of the dynamics - sometimes enriching, and more commonly devastating - of globalization. Founded as a penal colony on land seized from the Gadigal people, Sydney has for decades 
of land and the mass-production of consumable spaces. Bitten by a shining sun - and kissed by postcard beaches its digital print is full of consumable multiculturalism, a scenic sensation of global déjà vu and athletic, young and (re)productive, self-appreciated and consumed bodies, immune to the political. Well, 'politics' is an outdated term. In any case, decaffeinated versions of the political appear in museums, galleries, and television debates, almost always under the stamp of identity-politics, without making great efforts to hide the consumer format that contains them. In educational spaces, the political has long been declared non grata by the 'pragmatic' Australian institutional agendas. Instead, institutional officers have long copulated with the anti-human technological determinism of the smart, eroticizing with 'resilient' responses to the 'black clouds' announced by international science. In Sydney, the political - like its dark colonial past - was overtaken by a continuous and accelerating present, backed by almost half a century of uninterrupted economic growth.

As in any metropolis of 'instagrammic' aspiration, its soft aestheticization of the 'contemporary' denies an infinite, suburban and infrastructural backstage, seasoned with the sweat of disposable migrants, marginal clusters of indigenous presence, massive consumption of psychotropics and antidepressants by self-exploited entrepreneurs, the invisible elderly, and loneliness: an autochthonous loneliness, inseparable from the majority's embrace of the smiling authority of an economy without affections that recites by heart the psalms suggested by the Neoliberal Cognitive Apparatus ${ }^{\mathrm{TM}}$.

For its part, Valparaíso, monumental and dilapidated, looks at globalization with skepticism. A city that knows itself the loser of too many battles and has been whispered a lot of impossible promises. In its skin, worn and full of seams, tattoos and airbrush makeup, there is still the trace of the complex coexistence between abundance, misery, exchange, excess, and joy of her days as a global node. The once 'Jewel of the Pacific' is a city nursed, abused, and abandoned by capitalist globalization. Its bones accumulate fissures from earthquakes, sieges and various abandonments; its heart suffers from chronic disappointments, and its lungs never recovered from the suffocation of aporophobic fires. ${ }^{2}$ Forged from dissonant encounters, resistance and social conflicts, the city-port has become accustomed to living with failure, expropriation, abandonment, economic decline and nostalgia. 'Valpo' has been drowning on the margins of progress for almost a hundred years. Since the beginning of the $20^{\text {th }}$ century, the concatenation of global events such as the opening of the Panama Canal, the fall of the northern saltpeter empire, the anti-union repression of the 1980 s, the institutional abandonment, or the (privatizing) alienation of its beloved port, have turned the flows of capital between the outside world and the many and very diverse insides that make up the social cartography of its hills, its port and its 'plan' into thin drips.

Valparaíso is a bastion of negativity. It has survived its own death by clinging to networks of community solidarity, daily nods to the eschatological, 
cosmopolitical complicities, resistance, sweaty night covens, unproductive joys, precarious entrepreneurship, and rogue microeconomics. Despite all this, between the late 1990 s and 2003, the myopic gaze of politicians, 'experts' and businessmen imagined for Valparaíso an urban economy focused on the plasticized exploitation of its decadent industrial and architectural legacy, through its inclusion in the UNESCO World Heritage brand. Thus, an attempt was made to intravenously inject the idea that the city could house in its monumental, picturesque and deeply decadent architectures a Silicon Valley of international production and consumption of culture.

The Isaza report said so in 2016. Valparaíso is "dire" (Mosciatti, 2016). Today, it is as poor as before and more segregated than ever, since the unresolved rupture between city and port was joined by the social wall between the exploitable and disposable 'Valpo' (through fruitless gentrification and patrimonial demarcations) and the harassment and demolition of its bohemian 'heritage' (through legal fences at night). The Chilean city-port is not capable of crystallizing - nor rejecting - the (absurd) impulse to be turned into a picturesque consumer brand. They neither invested what was necessary for fattening the patrimonial project, nor did it want - or known how - to value its true legacy: negativity.

\section{Act 2: Trans-Pacific Shocks}

At the beginning of the 1970s, Chile and Australia started - by legitimately democratic means - two state projects with a socialist tendency. In just a few months, both political trials were ideologically demonized by extractive elites and violently overthrown after processes of socio-economic and political destabilization remotely controlled by the 'intelligence' of Anglo-American supremacism. The unilateral cancellation of both state projects gave rise to pioneering drifts of the neoliberal project.

In 1971, after nationalizing - with parliamentary support - a large part of heavy production and almost all of large-scale mining, the Chilean state activated the immunological response of the us empire and was plunged into a crossfire of figures, speeches, headlines, coded messages, protests and death, against a gaseous alliance between financial elites, members of the military, and the $\mathrm{CIA}$. The state of tension was inflamed vertiginously until it exploded in a violent coup on September 11, 1973. The military discipline of the dictatorship amputated aesthetic and ideological 'impurities' through a bloody display of repression, rapes, and murders against dissent. In parallel, and with little time to watch over the deceased revolution, a series of decree-laws (issued from the Chilean tentacles of the Chicago School of Economics, and among which the recently replaced $\mathrm{DL}-600^{3}$ stands out) provided the ideal legal substrate to activate the orgy of privatizing looting, overexploitation (of ecosystems and citizens), indebtedness and suffocating inflation that, as Claudio Lorca and José Ignacio Ponce (2013) remind us, reached its climax with the consolidation of the now questioned democratic project. Not in vain, despite the fact that the democratic turn re-established an indisputable package of rights and 


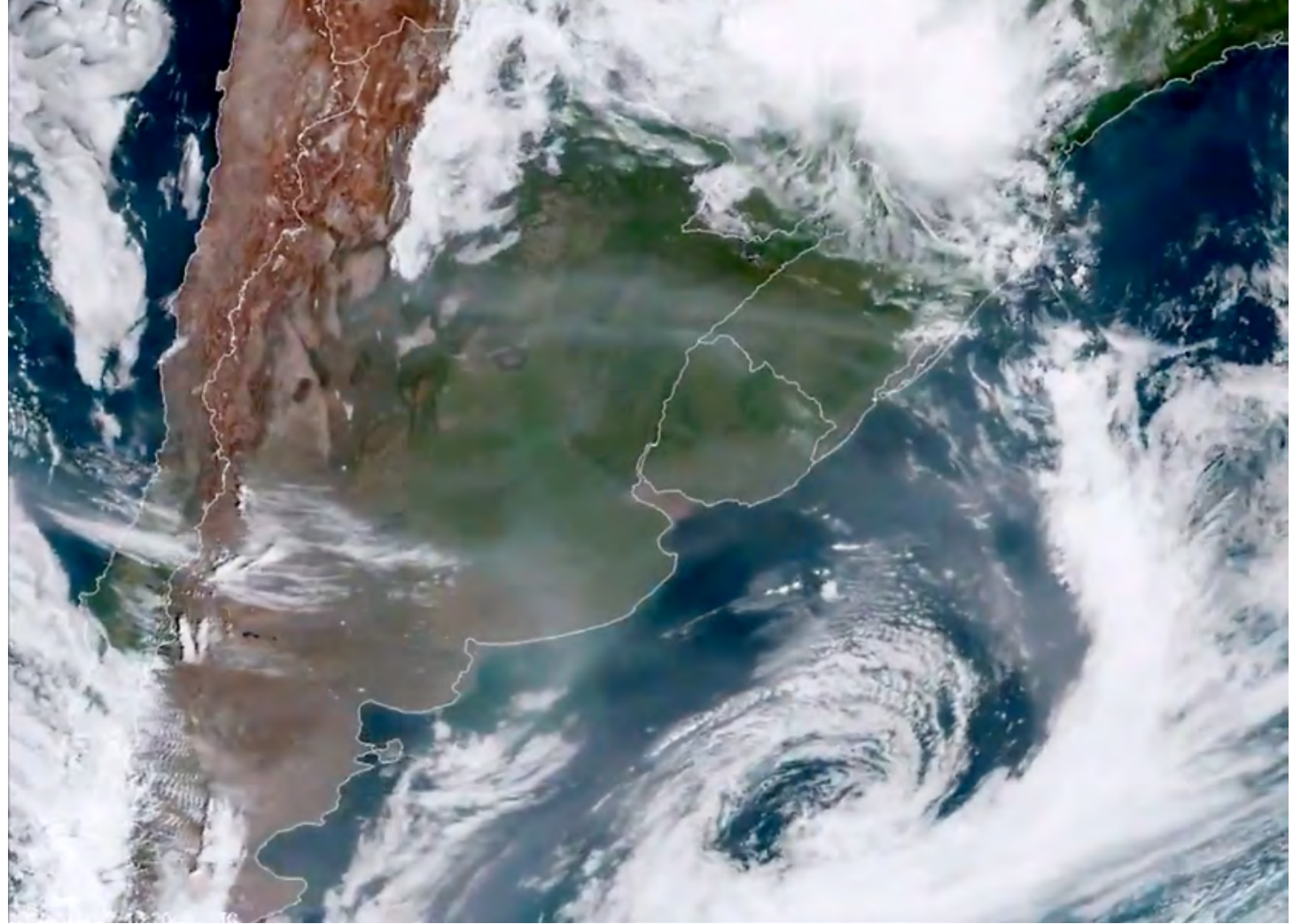

2 La Organización

Meteorológica Mundial de la ONU (OMM) informa que el humo de los furiosos incendios forestales en Australia se desplaza a través del Pacífico y llega América del Sur, enero de 2020. / The UN World Meteorological Organization (WMO) reports that smoke from raging bushfires in Australia drifts across the Pacific and reaches South America, January 2020.

(c) NOAA Satellites freedoms previously hijacked by the dictatorship, the democratic constitutional charter did not arise from a founding act, but instead applied an urgent patch on the 1980 Constitution. Thus, democracy facilitated an atmosphere of stability and reliability for the arrival of large extractive corporations, whose image was reinforced by entering 'legitimately' into a supposed rule of law.

Today, the social portrait of Chile draws a constellation of 'sacrificed' territories and citizenships (Acosta, 2019) for the cumulative benefit of global elites. The Andean state is a polarized hotbed that drowns the middle and poor classes under the suffocating gases of debt, inflation and precarious moonlighting, while condemning the loop of meritocratic stigma to 'choros', 'flaites', Mapuche, women, and so many other social redundancies with no place in the national neonarratives of 'effort' and 'success' of the misnamed 'Latin American Oasis' (The Clinic, 2018).

Australia didn't need a bloody shock to kick off its neoliberal orgy. Between 1972 and 1975, Labor Prime Minister Gough Whitlam raised Anglo-American alarms by betting on cutting economic, political and legal dependencies with the British crown, and by reinforcing an agenda loaded with 'alarmingly' left-wing projects. The Labor program began the partial dismantling of the hitherto in force White Policy. ${ }^{4}$ Migratory flows to Southeast Asia were opened and the aboriginal struggle was legitimized. Likewise, anti-laissez-faire measures were injected, and the then-succulent diplomatic-mercantile route was inaugurated with the always repudiated communist China. But Whitlam's socialist turn was not ignored by the (neo) imperial tentacles of the Anglo-Saxon universe. After a hotbed of parliamentary disputes, espionage schemes, and diplomatic interference from Buckingham Palace and 
Washington, on November 11, 1975, the Australian route was authoritatively dismantled by the Governor-General; ${ }^{5}$ a colonial entrenchment in the state apparatus, whose symbolic appearance masks its 'executive' power to dissolve parliaments and fire government teams at its own free will, or of its imperial interlocutors - in this case, the British crown and the CIA (Rundle, 2015).

The Whitlam phenomenon turned out to be a political cold for a citizenry accustomed to naturalizing colonial looting and living under flexible prison regimes, in exchange for partial redistributions of loot among their white pseudo-utopias. ${ }^{6}$ Australian cultural narratives have long operated under strict permissiveness towards authoritarian functionalisms (it is still known as the 'Nanny State'), and daily coexistence with neighborhood vigilantes (or 'neighbor watch'), incentives to obedient behaviors, and anti-otherness taxonomy based on ethnocultural supremacism, individualism, and anti-intellectuality. That is why, despite the monolithic authority with which popular sovereignty was attacked in 1975, the country's electorates resorted to the traditional cult of resilience to assimilate the new normal with hardly any resistance.

Today, the presentist mirages of 'democratic' consumption, of showy wages, of 'healthy' inflations, and 'aspirational' debts, have reformulated the desiring fabrics - and the common sense - of Australian citizens to turn them into a consensus bloc regarding the supreme and irreplaceable value of the contemporary hyperextractive model. The Australian postmodern drift has woven a resounding imagery of neoliberal success that devotes excessive attention to national pride and hides under bureaucratic carpets and media oligopolies (Dwyer and Muller, 2016) its social asymmetries and its extractive abuses of bodies and territories. The social gap between rich and poor Australians, as well as between white natives, migrants, and 'first nations,' have been masked through institutional make-ups of Aboriginal genocide, outsourcing of poverty (to disposable migrants ${ }^{7}$ ), and consumable products of the 'multicultural' diversity of the country. The icing on the structural 'micro-violence' 8 cake for Australian neoliberalism lies in its 'amiable' expulsion of dissent through 'pragmatic' amputations of aesthetic, unproductive and ideological content, of its cultural, educational and leisure programs.

If the Chilean neoliberal outbreak put the accent on oppressing the postcolonial delusions - or justice - of Latin American miscegenation with military discipline and archaic violence, its Australian counterpart was configured as a governance laboratory capable of hybridizing the necropolitical and its supremacist accent of the ReaganThatcher universe, with a 'psychopolitical' framework of parametric consensus in the purest Singapore style. In just half a century, the oceanic state has inadvertently transformed its citizens into 'post-political' audiences. Today, and with few exceptions, Australian citizens are, as Paul B. Preciado (2020) would say, "community utopias" addicted to consumption and allergic to ideological criticism. In their post-critical massiveness, they are facilitating the unbridled engulfment of their recursive 
and ecological wealth, their fundamental rights, and their simulacrum of national sovereignty, in favor of global corporate cartels.

\section{Act 3: Allegory of an Argumentative Twist}

The arrival of the Australian black cloud to Andean coasts resynchronized both ends of the Pacific to dramatize the vicissitudes of a new paradigm shift. The aeolian pilgrimage of forest smoke encapsulated Sydney and Valparaíso in an allegory of the end of an unsustainable rationality. The black cloud connected two cities besieged by a contemporaneity, unable to contain its necropolitical impulse. On January 7, 2020, Sydney had been suffocating for 57 days under the blanket of gas emitted by the most destructive fires in Australian history. The event was a spectacular manifestation of the planetary 'I can't breathe' - denounced endlessly by international science - and a kamikaze vendetta of Australian ecosystems after centuries of silenced abuses. At 11,000 $\mathrm{km}$ away, Valparaíso was looking for breathable air between barricade fumes and tear gas. The Chilean port city - just like other cities in the country at the time - had been fiercely fighting for almost three months against the tyrannical saga of economic measures implemented by a state devoted to the anti-citizen mandates spewed out by its 'expert committees' (Guzmán, 2019). Since October 2019, the main cities of the Chilean state hosted a viralization sparkled by a citizen protest against the increase in rates for metropolitan transport in Santiago. In a matter of days - accelerated also by state violence - the protests turned into widespread rebellion and fierce confrontations between citizen organizations - demanding 'dignity' - and state military bodies.

Through this essay, we are interested in reflecting on the need to review the transactional parameters around which neoliberalism has structured notions such as value, desirability, relevance and success. To do this, we forced an 'accidental' imaginary of coexistence between the urban and social fabrics of Sydney and Valparaíso, after being connected by the parenthesis of contemporary disasters denounced by the 'black cloud.' The joint reading of both incidents will allow us, on the one hand, to refute the international tendency to eagerly praise and reproduce urban and aesthetic imaginaries of post-political coexistence - under forced consensuses and transactional articulations of coexistence. On the other hand, it will help us to discredit the optimizing contempt with which hegemonic contemporaneity stigmatizes conceptions of urban coexistence loaded with negativities (aesthetic, unproductive, performative and ideological) unattainable by - and undesirable for - the neoliberal financial apparatus.

If in 2018, the Amazon honored Jair Bolsonaro and his denialist policies with disastrous fires, between August and September 2019, Anthropocene flames took over eastern Australian regions to unfold a spectacle of destruction and cosmopolitical rage that charred 19,000,000 hectares of forest, ruining rural economies and communities, and eradicating from the face of the 
buildings; and 33 people. ${ }^{9}$ The 'Australian Anthropocene Shame Tour 2019-20' traveled - between September and March - throughout the eastern states of the country, managing to besiege - with tragicomic malice - the beautiful, smiling and prosthetic Sydney for 81 days. Overnight, the opulent suburban fringes of its North Shore were cornered by several 'enemy fronts' (AlbeckRipka et al, 2020). In a matter of days, the metropolitan area of the emblematic Australian city was subjected to the pervasive omnipresence of a blanket of toxic smoke, for which the suburban bunkerization and the climate-controlled secrecy of its financial districts were easily transferable. In just weeks, more than 400 people died prematurely from respiratory problems. The city alternated days of 'poor' air quality index (AQI) with days that were simply unbreathable.

Paradoxically, this was only a few months after the political coalition constituted by white ethno-nationalists and ultra-liberal deniers won overwhelmingly in an election dominated by the environmental debate. Although Australia has spent years concatenating mass extinctions, devastating droughts, biblical floods, desiccation of river systems, and intensive bleaching of the coral reef (Sánchez et al, 2019), in the 'climate change elections' denialism and fear of emptiness won. The consensus with neoliberal agendas without a future won. Anglo-Saxon settler individualism and escapist anxiety to defend the colonial privilege of the Lucky Country won, ${ }^{10}$ whatever the cost and whoever is paying. The necropolitical agendas and the heteropatriarchal arrogance of the usual once again won. And so triumphed the approach to an end with the stale touch of Anglo-Saxon ethnocultural bunkerization that, in light of what we have seen, has gone from selling 'suburban' desires to betting on a little exciting planetary 'third worldization'; or what is the same: premature death for practically everyone, even for those who today speculate with it.

The government and its institutions responded to the summer disaster with vacations in Hawaii, insulting activists, and staunching support for the extraction of fossil fuels. Despite this, as well as deaths from suffocation, the growing eco-anxiety (understood as a psychological and, therefore, individual phenomenon), the volatilization of ancient ecosystems, the economic cost of climate change, mass extinctions, or the dehydration of the country, Sydney staged only one notable protest. It was on January 10 and it was labeled 'historic.' But the reality is that it brought together around 30,000 of its more than 5,000,000 inhabitants. The Australian black cloud caricatured the democratic, 'instagrammic' and successful cosmopolitanism of Sydney by showing us a docile, apathetic society, disconnected from the scale of its own tragedy, and without political weapons or sufficient critical capacity to discern its urgencies and enemies. Contemporary Sydney, despite its 'celebrated' multiculturalism, remains attached to a spatial settler tradition in which the ingredient 'street' neutralizes crossings and dissonant encounters; it works as a relay - connector/separator - between programmatic fragments and proprietary enclosures. Its urban project is the faithful heir to a social contract between white men 
allergic to the alien, who imagined themselves just 'passing by' an extractive paradise too far from 'the civilized.' The Australian city is calculated, designed, and regulated so that the expulsion of 'politics' does not require the exercise of 'macro-violence.' After all, Australia's neoliberal baptism demonstrated that economically 'successful' late-capitalist democracies are comfortable on colonial and authoritarian skeletons.

At the Andean end of the trans-Pacific cloud, the riots that began in October 2019 had peeled off a suffocating socioeconomic shell for almost everyone. Following a fee increase to the Transantiago, students, feminists, and other dissidents on the rise dragged swindled retirees, indebted and other 'homo sacer' of the ne(cr)oliberal-Chilean ${ }^{11}$ obscenity, to a revolutionary process that, despite the paralyzing effect of Covid-19, continues to set the pulse of current parliamentary debates. In the last decade, despite the fact that certain international rankings have drawn a country that is ahead in productivity, economic development, and social 'progress' compared to its regional neighbors, the recent legacy of deregulation, privatization, and inflation places the 'tiger' of Latin America in the third puts in the OECD ranking of economic inequality. ${ }^{12}$ To this, adds the anger at the patriarchal arrogance of a political class caricatured into a multimillionaire president, tightrope walker and so alienated from the Chilean social drama that, in the middle of the social outbreak, invented a 'war' against his fellow citizens and disarmed three decades of democratic 'assemblage,' militarizing the streets and allowing assassinations and violations of fundamental rights in the main cities of the country.

At the mercy of the social unrest, the hills, plan and port of Valparaíso indefinitely suspended their contractual pledge with UNESCO to recover their patrimonial ties with negativity. In a matter of days, the main arteries of the port-city turned the social harshness of 'Valpo' into a political carnival. The overflowing looting of department stores and supermarkets showed - for the umpteenth time - the socioeconomic marginality of a forgotten social heritage that claimed - with apprehended violence - its right to kick in the individualistic orgy of the present. The vandalism attacks on bank branches, franchises, corporate headquarters, and religious temples in the main arteries of the city, canceled the historical immunity of the puppeteers of a state at the service of the elites, especially allergic to the outpouring of subjectivities and worldviews printed in the Historic eclecticism of its iconic city.

The Valparaíso revolutionary 'parade' recovered the political force of graffiti after decades of forced services to the 'picturesque' portrait of urban elevators, multi-colored facades and, other still lifes of the UNESCO heritage imagery. Between the explosion of October 18 and the feminist catharsis of March 8, colonial 'heroes' monumentalized without popular permission were applied make-up, dressed up, and filled with post-heteropatriarchal symbolism. Each gesture staged the symbolic disassembly of a normality that had been confining the Chilean port for decades in irrelevance and multi-colonial stigma. 
The shared obstinacy to inhabit, dramatize, disguise, and permanently crowd the streets, affirmed that the demanded future is made by the protection of the supreme value of the common and the desire for the unregulated encounter with the alien. The programmatic agendas improvised by the collective fiction of the constituent Valparaíso were negotiated and tested in the estuarine fluidity of the 'street' space, colliding with each other commercial exchanges, shared vagrants, constituent processes, surveillance of the 'enemy,' joyous manifestations of the unproductive, and post-identity proprietary claims, who would only accept a city understood as a meeting point and as a permanent laboratory of imagined democratic practices.

In an ideological scuffle around the contemporary viability of revolutionary processes, the Korean philosopher Byung-Chul Han defended the impossibility of alluding to the 'revolution' without amassing critical awareness about the mechanisms of instrumentalization of desire deployed by the neoliberal 'stabilizing power.' Han (2014) provocatively defends that a "revolution is not possible," since its sting of destabilizing negativity requires a critical, generous and conscious community, currently neutralized by the neoliberal apparatus through permanent injections of doses (almost imperceptible) of narcissistic desire and fear of being left out. Against the Korean philosopher's argument, Marina Garcés (2014) angrily defends that revolution is not only possible but that it is happening permanently. Not as a platonic event but as a concatenation of transformations that are 'continually happening,' driven by those who have already been left out.

Without making romantic concessions to precariousness or violence, we must recognize that neoliberal (economic) success stories, such as Sydney, have run aground in a depressing narcissistic turn, whose fatal absence of interest in the alien leads to profound dystrophies of political imagination, and to suicidal returns to ethno-nationalist caves. For the same reason, it is convenient to recalibrate curiosity and cognitive interest towards the scenarios discarded by the 'efficient,' pragmatic and fragmented conception of globality that today suffocates us under necropolitical clouds. Wherever the mono-ideological and supremacist roller of global capitalism ran aground, it left unfinished its (optimizing) eradication of essential categories of coexistence, such as dissonance, ritual, unproductiveness, collectiveness, inefficiency, joy, absurdity, carnival, the unattainable, generosity, the unpredictable, the ugly, and the eschatological. The scenarios that until today we read as 'residues' of the epic (and necropolitical) advance of capitalist globalization, must be reviewed as 'exceptional testimonies' of living in 'negativity.' Perhaps then we will learn to reformulate relationships between cities, citizens, cultures, territories, and economies so that they can coexist without collapsing into the same figure.

Valparaíso, in all its boneless decadence, offers us in its urban diagram, its topographies, borders, flows, nocturnalities, and monumentalities, as well as in its mestizo multiculturalism (historical and present) and its 
banality, an architectural, urban and social palimpsest that, despite its recent break between the supposedly productive and the redundant, has not yet forgotten that the street is its social estuary; its facilitator of crosses, encounters, disagreements, and generous theatricalities open to the infinite proliferation of new existential grafts. If, as Camila Vergara (2019) says, the parliamentary achievements obtained after the social outbreak have turned Chile into a "laboratory for popular democracy," we are allowing ourselves the luxury and the audacity of 'nominating' the troubled, dysfunctional, theatrical and aware-of-its-suffocation Valparaíso as an alive - not 'museified' - political heritage of the infinite post-capitalist futures that remain to be imagined and inhabited, if we want to overcome the black clouds that the ne(cr)oliberal present bestows on us. ARQ

\section{Notas / Notes}

1 See: "Humo de incendios forestales de Australia Ilega a Chile y Argentina," SBS Spanish, January 7 , 2020, https://www.sbs.com.au/language/english/ humo-de-incendios-forestales-de-australia-llega-a-chile-y-argentina

2 The hills of Valparaíso have been surrounded by highly flammable forest plantations protected by the 1974 forest development law (D L-701). Added to this is the suburban and marginal condition of the population sectors bordering these plantations, in full infrastructural abandonment, with over-accumulation of rubbish and highly flammable 'informal' buildings.

3 Decree-Law 600 (Foreign Investment Statute) established a system of incentives and benefits for foreign investors to compete under a supposed 'equal conditions' framework with respect to local businessmen and public corporations. Its legal body facilitated the privatized exploitation of extractive resources and essential services (health, pension funds, supplies, education, and so on) until then covered by state companies.

4 The 'White Australia Policy' is the racist legal framework that governed both border policies and social orders in Australia until its abolishment in 1973

5 Until 1975, the Governor was Sir John Kerr.

6 There are several historical reasons that justify the passivity with which the Australian voter has allowed the anti-democratic violence against their country to pass. British colonial foundations framed the oceanic continent in a dual legal and cultural narrative of 'virgin territory' (or Terra Nullius) and 'prison state.' From the first settlements it made the natives invisible. Their cultural and civilizing legacy was denied in order to avoid negotiating conditions of occupation and management of the colonized territory. On the other hand, from 1788 forced labor was imported through the transfer of more than 160,000 British convicts. Those who did not die in miserable conditions of overcrowding and exploitation, were awarded for their good behavior with residual rights to join the colonial orgy.

7 The Australian visa model favors the temporary flow of floating populations essential to the country's economic backbone. In March 2020, about 2.17 million foreign workers were in temporary work visas and study visas (the latter, often used as a cover to access the 'benefits' of the Australian labor market). These workers lack social and health coverage from state institutions. Recently, given the economic impact of Covid-19, the Australian government refused to provide economic coverage to migrants unemployed by the phenomenon, and "strongly encouraged" temporary workers "unable to support themselves under these arrangements over the next six months to return home." Source: https://minister.homeaffairs.gov.au/davidcoleman/Pages/Coronavirusand-Temporary-Visa-holders.aspx. Consulted on May 10, 2020.

8 According to Byung-Chul Han, the neoliberal model has mutated the topology of paradigmatic violence from "visible to invisible, from frontal to viral, from direct to mediated, from real to virtual [and] from physical to psychic," turning from the imposing 'macrophysics' of 
9 See: $A B C$ News. "From A Single Lightning Strike to Australia's Largest Bushfire". Accessible at: https://www.abc.net.au/news/202002-19/australia-bushfires-how-heat-and-drought-created-atinderbox/11976134?nw=0

10 In 1964, Donald Horne published The Lucky Country, a critique of the anti-intellectual and passive character of white Australia. Ironically, today the term constitutes a hagiographic celebration of the legacy of four decades of uninterrupted economic growth.

11 We appropriate the term ne(cr)oliberalism, coined by Paul B. Preciado, as a fusion of the terms neoliberalism and necropolitical.

12 See: https://data.oecd.org/inequality/income-inequality.html. Consulted on July $8,2020$.

\section{Bibliografía / Bibliography}

ACOSTA, Sara. «¿Qué son las zonas de sacrificio de Chile?». El Diario, 5 de diciembre de 20I9. Disponible en / accessible at: https://www. eldiario.es/ballenablanca/365_dias/zonas-sacrificio-chile-cumbreclima_I_I205027.html.

ALBECK-RIPKA, Livia; KWAI, Isabella; FULLER, Thomas; TARABAY, Jamie. "It's an Atomic Bomb": Australia Deploys Military as Fires Spread» New York Times, 4 de enero de 2020. Disponible en / accessible at: https://www.nytimes.com/2020/or/o4/world/ australia/fires-military.html.

DWYer, Tim; MUller, Denis. «Factcheck: Is Australia's Level of Media Ownership Concentration One of The Highest in The World?». The Conversation, 8 de noviembre de 2020. Disponible en / accessible at: https://theconversation.com/factcheck-is-australias-levelof-media-ownership-concentration-one-of-the-highest-in-theworld-68437.

GARCÉs, Marina. «La revolución de lo posible». El País, 26 de diciembre de 20I4. Disponible en / accessible at: https://elpais.com/ ccaa/20I4/I2/26/catalunya/I4I96227I7_8I6659.html.

GUZM ÁN, Juan Andrés. «La responsabilidad de los "técnicos" de la élite en el I8/O». CIPER Chile, 23 de octubre de 20I9. Disponible en / accessible at: https://ciperchile.cl/20I9/10/23/la-responsabilidad-delos-tecnicos-de-la-elite-en-el-I8-o/.

HAN, Byung-Chul. «¿Por qué hoy no es posible la revolución?». El País, 3 de octubre de 20I4. Disponible en / accessible at: https://elpais.com/ elpais/2014/o9/22/opinion/I4II39677I_69I9I3.html.

LORCA, Claudio; PONCE, José Ignacio. «Nacionalización y privatización del cobre. una historia, nuestro presente, nuestro futuro». Le Monde Diplomatique (2013). Disponible en / accessible at: https://www. lemondediplomatique.cl/nacionalizacion-y-privatizacion-delcobre-una-historia-nuestro-presente-nuestro.html.
Mosciat Ti, Ezio. «Informe Isaza: un Valparaíso calamitoso y en riesgo como patrimonio de la humanidad». BioBioChile, 2 de junio de 20I6. Disponible en / accessible at: https://www.biobiochile.cl/ noticias/cultura/cultura-entretencion/2016/o6/o2/informe-isazaun-valparaiso-calamitoso-y-en-riesgo-como-patrimonio-de-lahumanidad.shtml.

PRECIADO, Paul B. «Aprendiendo del virus». El País, 28 de marzo de 2020. Disponible en / accessible at: https://elpais.com/ elpais/2020/03/27/opinion/1585316952_026489.html.

rodríguez, Miguel; Sánchez, Amaia; valiente, Jorge; valiente, Gonzalo. «Valparaíso post-liberal: 272 postales políticas». ARQ, no. 97 (2OI7): II3-II9.

rodríguez, Miguel; sánchez, Amaia; valıente, Jorge; valiente, Gonzalo. «Teatro della Terra Alienata. Australian national pavilion at the XxıI Milan Triennial». ARQ, no. I03 (2019): 40-49.

RUNDLE, Guy. «The Coup D'état That Unmade Australia» Crikey, II de noviembre de 2015. Disponible en / accessible at: https://www.crikey. com.au/20I5/II/II/rundle-the-coup-detat-that-unmade-australia/.

THE CLINIC. «La triste realidad del ascensor social en Chile: seis generaciones para romper la línea de la pobreza», The Clinic, I5 de junio de 20I8. Disponible en / accessible at: https://www.theclinic. cl/2018/o6/15/la-triste-realidad-del-ascensor-social-chile-seisgeneraciones-romper-la-linea-la-pobreza/.

vergara, Camila. «Chile Can Be A Laboratory of Popular Democracy». Jacobin, 23 de noviembre de 20I9. Disponible en / accessible at: https://www.jacobinmag.com/20I9/II/chile-protestspinochet-constitution-neoliberalism

\section{G RANDEZ A}

<gonzalo.valiente@uts.edu.au>

Constituted by Amaia Sánchez Velasco (1985) and brothers Jorge (1984) and Gonzalo Valiente (1982), together with the architect-writer Miguel Rodríguez Casellas (1966), who share much more than an interest in teaching, and a workplace - the UTS of Sydney. Within different perspectives, they have all experienced the new geographies of neoliberal violence and the need to re-politicize the way architecture is thought about and exercised. Far from addressing those commonplaces of reinvention and entrepreneurship, or technological determinism that coined innovation as the only way to relevance, the group explores design's material and discursive as a key tool for emancipation. 